\title{
Impact of the putative cancer stem cell markers and growth factor receptor expression on the sensitivity of ovarian cancer cells to treatment with various forms of small molecule tyrosine kinase inhibitors and cytotoxic drugs
}

\author{
SOOZANA PUVANENTHIRAN ${ }^{1}$, SHARADAH ESSAPEN ${ }^{2}$, ALAN M. SEDDON $^{1}$ and HELMOUT MODJTAHEDI ${ }^{1}$ \\ ${ }^{1}$ School of Life Sciences, Pharmacy and Chemistry, Kingston University London, Kingston-upon-Thames, \\ Surrey KT1 2EE; ${ }^{2}$ St Luke's Cancer Centre, Royal Surrey County Hospital, Guildford GU2 7XX, UK
}

Received June 21, 2016; Accepted August 22, 2016

DOI: $10.3892 /$ ijo.2016.3678

\begin{abstract}
Increased expression and activation of human epidermal growth factor receptor (EGFR) and HER-2 have been reported in numerous cancers. The aim of this study was to determine the sensitivity of a large panel of human ovarian cancer cell lines (OCCLs) to treatment with various forms of small molecule tyrosine kinase inhibitors (TKIs) and cytotoxic drugs. The aim was to see if there was any association between the protein expression of various biomarkers including three putative ovarian cancer stem cell (CSC) markers (CD24, CD44, CD117/c-Kit), P-glycoprotein (P-gp), and HER family members and response to treatment with these agents. The sensitivity of 10 ovarian tumour cell lines to the treatment with various forms of HER TKIs (gefitinib, erlotinib, lapatinib, sapitinib, afatinib, canertinib, neratinib), as well as other TKIs (dasatinib, imatinib, NVP-AEW541, crizotinib) and cytotoxic agents (paclitaxel, cisplatin and doxorubicin), as single agents or in combination, was determined by SRB assay. The effect on these agents on the cell cycle distribution, and downstream signaling molecules and tumour migration were determined using flow cytometry, western blotting, and the IncuCyte Clear View cell migration assay respectively. Of the HER inhibitors, the irreversible pan-TKIs (canertinib, neratinib and afatinib) were the most effective TKIs for inhibiting the growth of all ovarian cancer cells, and for blocking the phosphorylation of
\end{abstract}

Correspondence to: Professor Helmout Modjtahedi, School of Life Sciences, Pharmacy and Chemistry, Kingston University London, Penrhyn Road, Kingston-upon-Thames, Surrey KT1 2EE, UK E-mail: h.modjtahedi@kingston.ac.uk

Abbreviations: EGFR, epidermal growth factor receptor; HER, human epidermal growth factor receptor; CSC, cancer stem cells; IGF-IR, insulin-like growth factor receptor I; CD44, cluster differentiation 44; CD24, cluster differentiation 24; ALK, anaplastic lymphoma kinase; c-MET, hepatocyte growth factor receptor

Key words: ovarian cancer, EGFR, HER-2, cancer stem cell markers, afatinib, dasatinib, neratinib, IGF-1R, paclitaxel
EGFR, HER-2, AKT and MAPK in SKOV3 cells. Interestingly, while the majority of cancer cells were highly sensitive to treatment with dasatinib, they were relatively resistant to treatment with imatinib (i.e., $\mathrm{IC}_{50}>10 \mu \mathrm{M}$ ). Of the cytotoxic agents, paclitaxel was the most effective for inhibiting the growth of OCCLs, and of various combinations of these drugs, only treatment with a combination of NVP-AEW541 and paclitaxel produced a synergistic or additive anti-proliferative effect in all three cell lines examined (i.e., SKOV3, Caov3, ES2). Finally, of the TKIs, only treatment with afatinib, neratinib and dasatinib were able to reduce the migration of HER-2 overexpressing SKOV3 cells. We did not find any significant association between the expression of putative ovarian CSC marker, HER family members, c-MET, ALK, and IGF-IR and the response to the irreversible HER TKIs. Our results support the need for further investigations of the therapeutic potential of these irreversible HER family blockers in ovarian cancer, and the therapeutic potential of dasatinib when used in combination with the inhibitors of the HER family members in ovarian cancer.

\section{Introduction}

Ovarian cancer is one of the most aggressive and lethal types of gynecological cancer. Worldwide, it was responsible for an estimated 152,000 deaths in 2012 (1). At present, the standard treatment for patients with ovarian cancer comprises of maximum surgical debulking, which is then followed by adjuvant chemotherapy, entailing a combination of a platinum compound with a taxane (2-4). However, the great majority of ovarian cancer cases are diagnosed in patients at an advanced stage of the disease and they have a poor response to currently available therapeutic interventions. As a result, the 5-year survival rates for ovarian cancer patients who are diagnosed at stages I/II and III/IV is 90 and $20-40 \%$ respectively $(2,5)$. This highlights the urgent need for the development of novel and more effective therapeutic agents with different mechanisms of action, and the identification of biomarkers for use in the early detection of such cancers and for the selection of relevant patient populations who may benefit from such therapeutic interventions $(3,6-8)$. 
Since the early 1980s, aberrant expression and activation of human epidermal growth factor receptor (EGFR), which is the prototype of the type I growth factor receptor family (also known as ErbB/HER family), has been reported in a wide range of human cancers (9-11). The EGFR transmits the mitogenic action of seven ligands including EGF, TGF $\alpha$, HB-EGF, amphiregulin, BTC, and AREG. The binding of ligands to the extracellular domain of the EGFR results in the formation of EGFR homo-dimerisation or its heterodimerisation with the other three members of the EGFR family, which include HER-2 (Neu, c-ErbB-2), HER-3 (ErbB-3) and HER-4 (ErbB-4), the autophosphorylation of such receptor, and ultimately leading to activation of several downstream adaptor/signaling molecules including the ras/ raf/MAPK, PI3K/Akt, PLC-Y and JAK/STAT pathways. Such biochemical signaling in turn sets off the cancer hallmark which include increased tumour cell proliferation and migration and invasion (12-15).

Increased expression and activation of HER family members have been reported in a wide range of epithelial tumours, including ovarian cancer, and in some ovarian cancer studies they have been associated with a poorer prognosis (16-19). To date, several monoclonal antibodies and small molecule tyrosine kinase inhibitors specific for the HER members have been approved for the treatment of patients with colorectal, head and neck, breast, stomach, lung and pancreatic cancers $(11,20)$. However, none of these inhibitors has yet been approved for the treatment of ovarian cancers, and this may be due the heterogeneous nature of ovarian cancer and the lack of reliable biomarkers for response to such therapeutic interventions (21-26). Moreover, in some studies the presence of a small subpopulation of tumour cells, called cancer stem cells, is thought to be responsible for the poor response and the development of resistance to therapeutic interventions (27-29).

Therefore, in this study, we investigated the sensitivity of a large panel of human ovarian cancer cell lines to treatment with various forms of EGFR TKIs including reversible EGFR specific, and reversible and irreversible pan-ErbB family inhibitors. In addition, we determined the effect of other inhibitors including dasatinib (v-abl/src/c-Kit TKI), imatinib (v-abl/c-Kit/PDGFR TKI), NVP-AEW541 (IGF-1R inhibitor), crizotinib (C-met/Alk inhibitor) and cytotoxic agents (paclitaxel, cisplatin and doxorubicin) on the growth of the ovarian cancer cells, and whether there was any association between the expression of various biomarkers such as putative ovarian cancer stem cell (CSC) markers (e.g., CD24, CD44, CD117/ c-Kit), P-glycoprotein (P-gp), and HER family members and their responses to treatment with these agents.

\section{Materials and methods}

Tumour cell lines. Of ten human ovarian tumour cell lines examined in this study, SW626, PA1, ES2, Caov3 and Ovcar-3 were purchased from American Type Culture Collection (Manassas, VA, USA) and SKOV3, Cov318, A2780, A2780 CIS and $\mathrm{A} 2780^{\mathrm{ADR}}$ were purchased from the European Collection of Cell Culture (Porton Down, UK). Caov3, SKOV3, Cov318, PA1 and ES2 were cultured in Dulbecco's modified Eagle's medium (DMEM) (Sigma, UK), A2780, A2780 CIS, A2780 ADR and Ovcar-3 in Roswell Park Memorial Institute-1640 medium
(RPMI-1640) (Sigma), and SW626 cells in Liebovitz's L-15 medium (L-15). All media were supplemented with $10 \%$ fetal calf serum (FCS) (Sigma) and the antibiotics penicillin, streptomycin, neomycin. All RPMI and Liebovitz medium were also supplemented with glutamine (Sigma). Drug-resistant cell lines A2780 ${ }^{\mathrm{CIS}}$ and A2780 $\mathrm{ADR}$ were also supplemented with cisplatin (1 $\mu \mathrm{M}, 2-3$ passages) and doxorubicin (100 $\mathrm{nM}$, once a week) respectively to maintain their resistant phenotype.

Antibodies, tyrosine kinase inhibitors, and other reagents. The IGF-1R TKI NVP-AEW541, the reversible EGFR TKI erlotinib (OSI-774), and irreversible pan-HER family blocker afatinib (BIBW2992) were kindly provided by Novartis (Switzerland), OSI Pharmaceuticals (Farmingdale, NY, USA), Boehringer Ingelheim (Austria) respectively. Sapitinib (AZD8931), lapatinib (GW-572016 ditosylate), canertinib (CI-1033), imatinib, dasatinib and neratinib (HKI-272) were purchased from Selleckhem (Suffolk, UK), crizotinib and gefitinib (Tocris, Bristol/Macclesfield, UK). The cytotoxic drugs paclitaxel, doxorubicin and cisplatin and the mouse anti-EGFR mAb F4 were purchased from Sigma-Aldrich (Dorset, UK). The mouse monoclonal antibodies against HER-3 (MAB3481), HER-4 (MAB11311), IGF-IR (MAB391), ALK (MAB77491), and HGF R/c-MET (MAB3583) were purchased from R\&D Systems (Oxford, UK) and those against CD24 (55426), CD44 (555476), CD117/c-Kit (555713) and P-glycoprotein (557001) were purchased from Becton-Dickinson Ltd., (Oxford, $\mathrm{UK})$ respectively. The primary in-house mouse antibodies HM50.67A and HM43.16B were raised against the external domain of HER-2 and EGFR respectively (30). The mouse anti-IGF-IR and the rabbit anti-pIGF-1R antibodies were purchased from Insight Biotechnology (Middlesex, UK). The mouse phosphor-Ty-100 and the rabbits anti-phosphorEGFR, HER-2, phosphor-HER-2, HER-3, phosphor-HER-3, phosphor-HER-4, HER-4, MAPK, phosphor-MAPK, Akt, phosphor-Akt, Met, phospho-Met, Stat-3, phosphor-stat-3, Stat-5, phospho-stat-5, $\beta$-actin, and $\mathrm{CD} 44^{+}$were all purchased from Cell Signaling Technology (Hitchin, UK). The antimouse IgG FITC conjugated STAR9B was from Serotec Ltd. (Oxford, UK), and the alkaline phosphatase conjugated goat anti-mouse IgG and anti-rabbit IgG were from Fisher Scientific Ltd. (Loughborough, UK). The donkey anti-rabbit IgG IRDye 680RD and goat anti-mouse IgG IRDye 800CW were purchased from LI-COR Ltd. (Cambridge, UK).

Flow cytometry. The cell surface expression of the HER family members, IGF-IR, ALK, c-MET, putative CSC and P-glycoprotein markers was determined using flow cytometry, as described previously (31). Briefly, $\sim 1 \times 10^{6}$ cells in $1 \mathrm{ml}$ of $2 \%$ FBS medium were incubated in the presence of primary mouse antibody or control medium for $1 \mathrm{~h}$ by rotation at $4^{\circ} \mathrm{C}$. The tumour cells were then washed three times by centrifugation, and then incubated in the presence of the FITC-conjugated rabbit anti-mouse IgG secondary antibody for $1 \mathrm{~h}$ by rotation at $4^{\circ} \mathrm{C}$. Cells were again washed three times by centrifugation, and the cell pellet was finally re-suspended in FACS Flow buffer (Becton-Dickinson). A minimum of 10,000 events were recorded through excitation with an argon laser at $488 \mathrm{~nm}$ and data were analysed using the FITC detector (at $525 \mathrm{~nm}$ ) of BD FacsCalibur flow cytometer (Becton-Dickinson), and 
mean fluorescence intensity values were calculated using CellQuest pro software (Becton-Dickinson).

Growth response studies. The effect of the various agents on the growth of human ovarian cancer cell lines was determined using the sulforhodamine B (SRB) colourimetric assay (Sigma-Aldrich), as described previously (31). Briefly, tumour cells were seeded at a density of 5,000 cells per well in $100 \mu \mathrm{l}$ of growth medium supplemented with $2 \%$ FBS in a 96-well plate. Following $4-\mathrm{h}$ incubation at $37^{\circ} \mathrm{C}, 100 \mu \mathrm{l}$ aliquots of doubling dilutions of the drugs or control medium (i.e., without drug) were added to triplicate wells. Cells in the 96-well plates were then incubated at $37^{\circ} \mathrm{C}$ until cells in the wells containing the control medium were almost confluent. Tumour cells were then fixed with $10 \%$ trichloroacetic acid (TCA) for $1 \mathrm{~h}$ and were gently washed with tap water, air-dried for $\sim 24 \mathrm{~h}$, and then stained with $0.04 \%$ sulforhodamine B (SRB) in $1 \%$ acetic acid for further $1 \mathrm{~h}$. Each plate was then washed with $1 \%$ acetic acid, air dried overnight and the SRB stain was solubilized by adding $100 \mu \mathrm{l}$ of $10 \mathrm{mM}$ Tris-base per well. The absorbance of each well was measured at $565 \mathrm{~nm}$ using the Epoch plate reader (Thermo Fisher, UK). To determine the initial number of cells prior to treatment, an extra plate of cells was set up and processed under the same condition after 4-h incubation at $37^{\circ} \mathrm{C}$ without the drugs. Growth as percentage of growth of control was determined through the following formula: $\%$ Growth $=\mathrm{B}-\mathrm{A} / \mathrm{C}-\mathrm{A} \times 100$, where $\mathrm{A}=\mathrm{A} 565 \mathrm{~nm}$ before treatment, $\mathrm{B}=\mathrm{A} 565 \mathrm{~nm}$ after treatment with drugs, and $\mathrm{C}=$ A565 nm after medium (32). The $\mathrm{IC}_{50}$ value of each agent was determined using Gen5 software (BioTek, UK).

Determination of combination index. The effect of two agents, when used in combination, on the growth of ovarian cells was determined, using the combination index (CI) as described previously (32). Briefly, the drugs for each combination were mixed at $8 \mathrm{X}$ their $\mathrm{IC}_{50}$ value followed by 8 doubling dilutions (32). Data analysis was then performed using CalcuSyn software (Biosoft, UK). The combination index values $<0.9$ indicates synergistic effect, while CI values between 0.90-1.10 indicates an additive effect and CI values $>1.1$ denotes antagonistic effect.

Western blot analysis. Tumour cells were grown to near confluency in 6-well culture plates containing $5 \mathrm{ml}$ of $10 \% \mathrm{FBS}$ growth medium. Cells were washed once with $5 \mathrm{ml}$ of $0.5 \%$ FCS/medium and then incubated in $5 \mathrm{ml}$ of fresh $0.5 \%$ medium containing no drug (control), a TKI, or a cytotoxic drug for $24 \mathrm{~h}$ at $37^{\circ} \mathrm{C}$, prior to treatment with the HER ligand heregulin $(20 \mathrm{nM})\left(\mathrm{R} \& \mathrm{D}\right.$ Systems) for $15 \mathrm{~min}$ at $37^{\circ} \mathrm{C}$. Tumour cells were then lysed in $400 \mu \mathrm{l}$ of lysis buffer (Invitrogen, Paisley, UK) containing the cocktail protease inhibitor (Sigma-Aldrich). Cell lysates were heated to $75^{\circ} \mathrm{C}$ for $10 \mathrm{~min}$, then $30 \mu \mathrm{l}$ of protein samples $(30 \mu \mathrm{g})$ were separated on $4-12 \%$ Bis-Tris gels (Invitrogen) and transferred onto polyvinylidene difluoride (PVDF) membranes using the XCell II Mini-Cell Blot Module kit (Invitrogen). PVDF membranes were probed with antibodies using SNAP i.d systems (Millipore, Watford, UK). Signal for all were detected using either the Western Breeze chemiluminescence kit (alkaline-phosphatase conjugated secondary antibody, Invitrogen) and visualized by the G-box imaging system (Syngene, Cambridge UK) or a fluorescence conjugated secondary antibody (LI-COR Ltd) and visualized by the accompanying software, LI-COR Image Studio.

Cell cycle distribution analysis. The effect of various agents on the cell cycle distribution of ovarian cancer cell lines was determined using flow cytometry as described previously (32). Approximately $2.5 \times 10^{5}$ cells were seeded into $25 \mathrm{~cm}^{2}$ culture flasks containing $10 \mathrm{ml}$ of $2 \%$ FBS growth medium plus no drug (control medium) or an agent. Once the cells containing medium only were almost confluent in the control flasks, the cells were harvested and pooled together with the cell supernatant, and washed three times with cold PBS. The final cell pellet was re-suspended in $200 \mu \mathrm{l}$ of cold PBS, and permeabilised by the addition of cold $70 \%$ ethanol overnight at $4^{\circ} \mathrm{C}$. The tumour cells were then washed once with PBS and incubated with $0.5 \mathrm{ml}$ of PI/RNAse mix (Becton-Dickinson) for $\sim 35 \mathrm{~min}$ at room temperature. The PI-stained tumour cells were then excited at $488 \mathrm{~nm}$ using the FL-3 detector $(620 \mathrm{nM})$ of a BD FACsCalibur flow cytometer (Becton-Dickinson), and analysed using CellQuest Pro software (Becton-Dickinson).

Migration assay. The cell migration assay was conducted using the IncuCyte Clear View 96-well cell migration plate according to the manufacturer's instructions (Essen Bioscience Ltd., Hertfordshire, UK). Briefly, $\sim 1 \times 10^{3}$ tumour cells plus the treatment in total volume of $60 \mu 10.5 \%$ FBS medium were added into Clear View 96-well insert. Each cell plate was then left to settle at the room temperature for $15 \mathrm{~min}$ followed by incubation for a further $30 \mathrm{~min}$ at $37^{\circ} \mathrm{C}$. Then $200 \mu \mathrm{l}$ of medium containing $10 \%$ FBS (chemoattractant) was added to the lower chamber. The cell plate was then placed onto the IncuCyte Zoom ${ }^{\circledR}$ instrument and were left for $15 \mathrm{~min}$ at $37^{\circ} \mathrm{C}$ to settle. After careful removal of any condensation on the lid or bottom of the reservoir, each plate was returned into IncuCyte Zoom instrument with a 10x objective using the IncuCyte ${ }^{\mathrm{TM}}$ chemotaxis system. Chamber wells were analysed every $3 \mathrm{~h}$ using the IncuCyte chemotaxis software.

Statistical analysis. Linear regression was used to analyse the relationship between the expression of the HER family receptors in response to treatment with afatinib, erlotinib, crizotinib, NVP-AEW541 and cytotoxic drugs. A one-way analysis of variance (ANOVA) test was used to compare mean values between more than two groups. Data are presented as mean \pm SD. $\mathrm{P}<0.05$ was considered statistically significant.

\section{Results}

Growth factor receptors and putative cancer stem cell marker expression in ovarian cancer cells. The cell surface expression of HER-family members (EGFR/HER-1, HER-2/neu, HER-3 and HER-4) was determined by FACS analysis. Of the 10 ovarian cell lines examined, SW626, ES2, SKOV3, and Caov3 were moderately positive for the EGFR with the mean fluorescence intensity (MFI) values of 10, 15, 15 and 40, and respectively (Table I). Of the seven HER-2 positive cancer cell lines, HER-2 overexpression was only detected in SKOV3 cells (MFI=574) (Table I). SKOV3 cells were also found to be positive for the expression of IGF-IR and c-MET. In contrast, 
all ovarian tumour cell lines had undetectable levels of both HER-3 and HER-4. The highest level of IGF-IR, ALK and c-MET were present in A2780 ${ }^{\mathrm{CIS}}$ (MFI=13), Cov318 (MFI=11), and Cov318 (MFI=24) (Table I). Of the putative cancer stem cell markers, 5 cell lines were CD24-positive, with the highest level of CD24 expression in SKOV3 cells (MFI=440), and 6 cells lines were CD44-positive with the highest level of CD44 in ES2 (MFI=1,105). Finally, none of the ovarian cancer cell lines had overexpression of P-glycoprotein and all were found to be CD117/c-Kit-negative (Table I).

The irreversible pan-HER inhibitors were more effective than the reversible EGFR inhibitors at inhibiting the growth of ovarian cancer cells. Of the TKIs, the two reversible EGFR TKI gefitinib and erlotinib inhibited the growth of 6 and all 10 ovarian cancer cell lines with $\mathrm{IC}_{50}$ values ranging from $1.82 \mathrm{nM}$ (Caov3) to $5.5 \mu \mathrm{M}$ (A2780), and $152 \mathrm{nM}$ (Caov3) to $9.6 \mu \mathrm{M}\left(\mathrm{A} 2780^{\mathrm{ADR}}\right)$ respectively (Table I). The reversible dual EGFR/HER-2 lapatinib inhibited the growth of 9 cancer cell lines, with $\mathrm{IC}_{50}$ values ranging from $1.42 \mathrm{nM}$ (SKOV3) to $5.28 \mu \mathrm{M}$ (A2780). At cutoff value of $10 \mu \mathrm{M}$, the reversible EGFR/HER-2/HER-3 TKI sapitinib was less effective than the irreversible pan-HER family blockers (i.e., canertinib, neratinib and afatinib) at inhibiting the growth of ovarian cancer cells, and its $\mathrm{IC}_{50}$ values were $>10 \mu \mathrm{M}$ for three ovarian cancer cell lines ES2, Cov318 and Ovcar-3 (Table II and Fig. 1A). Canertinib, neratinib and afatinib were the best cytotoxic HER TKIs and they inhibited the growth of all ovarian cancer cells with $\mathrm{IC}_{50}$ values ranging from $57.6 \mathrm{nM}$ (Caov3) to $3.55 \mu \mathrm{M}$ (SW626), $1.38 \mathrm{nM}$ (Cov318) to $927 \mathrm{nM}$ (SW626), and $83 \mathrm{nM}$ (Caov3) to $1.4 \mu \mathrm{M}$ (ES2) respectively (Table II and Fig. 1A). At nM concentration, the IGF-IR TKI NVP-AEW541 was only effective at inhibiting the growth in vitro of PA1 cells $\left(\mathrm{IC}_{50}=79.3 \mathrm{nM}\right)$. The ALK/c-MET inhibitor crizotinib inhibited the growth of all ovarian cancer cell lines with $\mathrm{IC}_{50}$ values ranging from $162 \mathrm{nM}$ (PA1) to $2.7 \mu \mathrm{M}$ $\left(\mathrm{A} 2780^{\mathrm{ADR}}\right)$. Interestingly, the majority of ovarian cancer cells were highly sensitive to treatment with dasatinib with $\mathrm{IC}_{50}$ values of $<26 \mathrm{nM}$, but all were relatively resistant to treatment with imatinib (i.e., $\mathrm{IC}_{50}$ value $>10 \mu \mathrm{M}$, Table II and Fig. 1B). Of the three cytotoxic drugs used in this study, paclitaxel was the most effective agent at inhibiting the proliferation of ovarian cancer cell lines [ $\mathrm{IC}_{50}$ range: $102 \mathrm{pM}$ (Caov3) to $278 \mathrm{nM}$ (Ovcar-3)], followed by doxorubicin. Interestingly, the great majority of ovarian cancer cells were relatively resistant to treatment with cisplatin and had an $\mathrm{IC}_{50}>20 \mu \mathrm{M}$ (Table II and Fig. 1B).

Treatment with TKIs increases the population of ovarian cancer cells in sub- $G_{1}$ and $G_{2} / M$ phase. We examined the effect of treatment with various agents on the cell cycle distribution of ovarian cancer cells. As shown by flow cytometry, SKOV3 cells have the highest level of HER-2 expression, low levels of EGFR, IGF-IR and c-MET expression, and overexpress the two putative ovarian cancer stem cell markers (Table I). As a result, SKOV3 cells were selected for comparing the effect of various forms of inhibitors (i.e., reversible EGFR, irreversible pan-HER inhibitor, IGF-IR TKI, C-MET-TKI) with cytotoxic drugs on cell cycle distribution. Treatment of SKOV3 cells with both the cytotoxic drugs paclitaxel and doxorubicin 


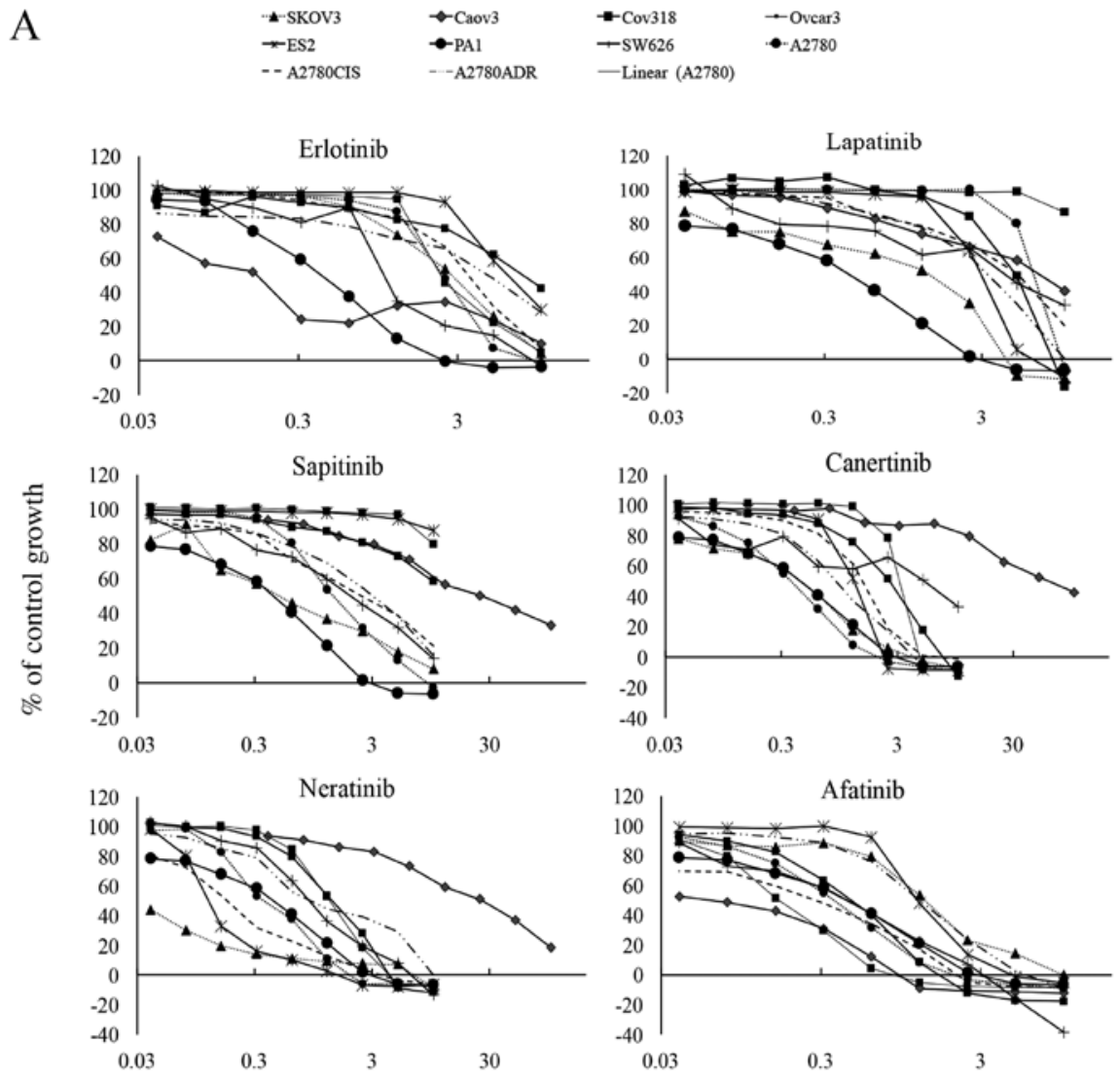

Drug concentration $(\mu \mathrm{M})$

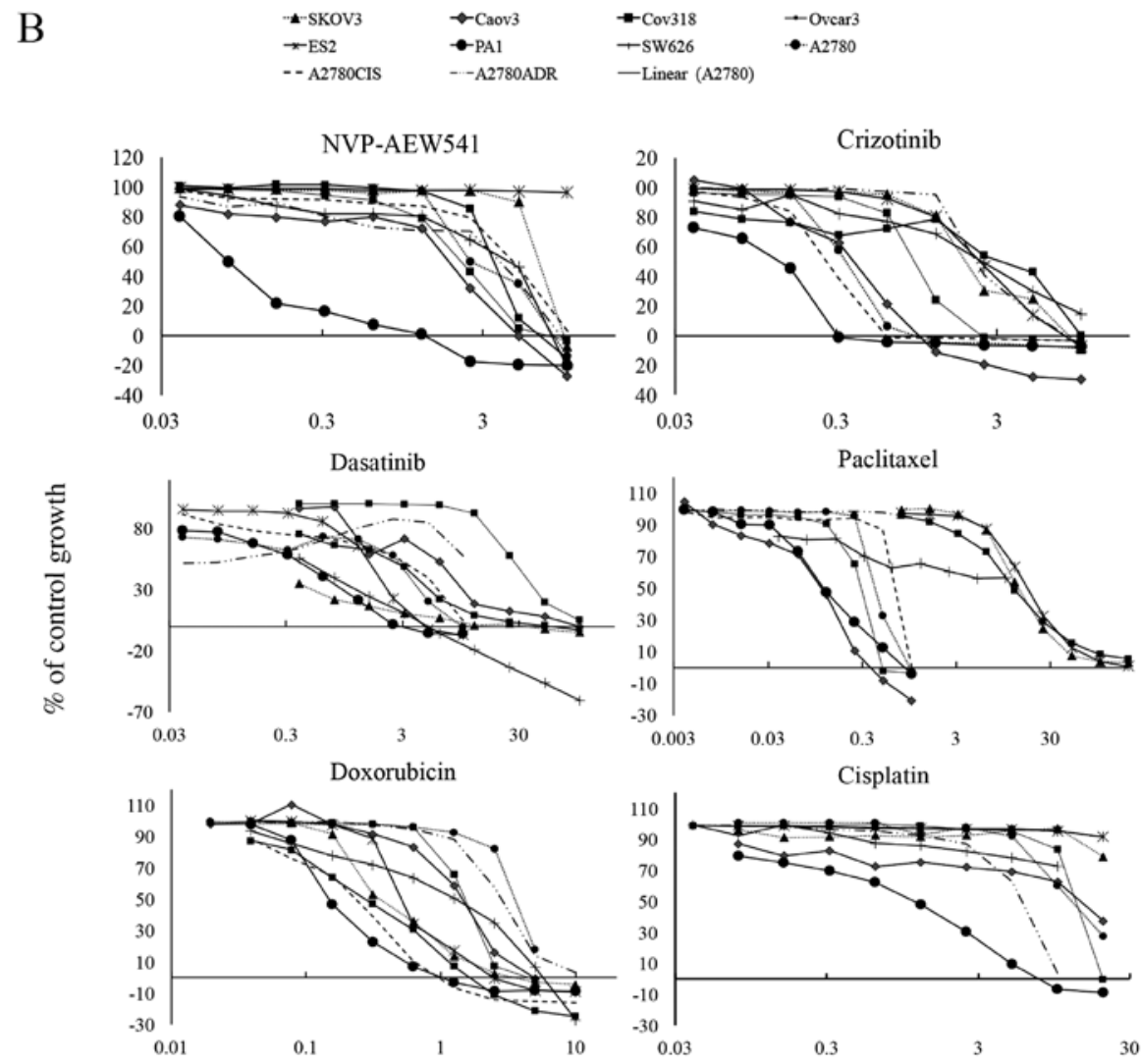

Drug concentration $(\mu \mathrm{M})$

Figure 1. (A) Effect of doubling dilutions of HER TKIs and (B) other TKIs and cytotoxic agents on growth of human ovarian cancer cells. Tumour cells were grown in growth medium ( $2 \%$ FBS) with inhibitors or medium alone until control cells (only medium) were confluent. The proliferation of cancer cells was calculated as percentage of control cell growth, as described in Materials and methods. Each point is a representation of the mean \pm SD. 
Table II. $\mathrm{IC}_{50}$ values for various types of HER TKIs (A), and other TKIs and cytotoxic agents (B) in human ovarian cancer cell lines.

$\mathrm{A}, \mathrm{IC}_{50}$ values for various types of HER TKIs

\begin{tabular}{|c|c|c|c|c|c|c|c|}
\hline Cell lines & Gefitinib & Erlotinib & Lapatinib & Sapitinib & Canertinib & Neratinib & Afatinib \\
\hline ES2 & $>10 \mu \mathrm{M}$ & $5.6 \mu \mathrm{M}$ & $2.9 \mu \mathrm{M}$ & $>10 \mu \mathrm{M}$ & $1.4 \mu \mathrm{M}$ & $125 \mathrm{nM}$ & $1.4 \mu \mathrm{M}$ \\
\hline PA1 & $5.3 \mathrm{nM}$ & $420 \mathrm{nM}$ & $2.2 \mu \mathrm{M}$ & $4.4 \mu \mathrm{M}$ & $1.1 \mu \mathrm{M}$ & $458 \mathrm{nM}$ & $555 \mathrm{nM}$ \\
\hline SKOV3 & $2.3 \mu \mathrm{M}$ & $2.4 \mu \mathrm{M}$ & $1.4 \mathrm{nM}$ & $584 \mathrm{nM}$ & $449 \mathrm{nM}$ & $23 \mathrm{nM}$ & $1.4 \mu \mathrm{M}$ \\
\hline CAOV3 & $1.8 \mathrm{nM}$ & $152 \mathrm{nM}$ & $53.6 \mathrm{nM}$ & $24.3 \mathrm{nM}$ & $57.6 \mathrm{nM}$ & $28 \mathrm{nM}$ & $83 \mathrm{nM}$ \\
\hline COV318 & $>10 \mu \mathrm{M}$ & $7.5 \mu \mathrm{M}$ & $4.6 \mu \mathrm{M}$ & $>10 \mu \mathrm{M}$ & $2.6 \mu \mathrm{M}$ & $1.4 \mathrm{nM}$ & $451 \mathrm{nM}$ \\
\hline SW626 & $3.3 \mu \mathrm{M}$ & $1.3 \mu \mathrm{M}$ & $3.4 \mu \mathrm{M}$ & $2.3 \mu \mathrm{M}$ & $3.6 \mu \mathrm{M}$ & $927 \mathrm{nM}$ & $445 \mathrm{nM}$ \\
\hline OVCAR3 & $>10 \mu \mathrm{M}$ & $2.3 \mu \mathrm{M}$ & $>10 \mu \mathrm{M}$ & $>10 \mu \mathrm{M}$ & $2.6 \mu \mathrm{M}$ & $1.3 \mathrm{nM}$ & $165 \mathrm{nM}$ \\
\hline A2780 & $5.5 \mu \mathrm{M}$ & $2.4 \mu \mathrm{M}$ & $5.3 \mu \mathrm{M}$ & $1.7 \mu \mathrm{M}$ & $1.2 \mu \mathrm{M}$ & $373 \mathrm{nM}$ & $365 \mathrm{nM}$ \\
\hline $\mathrm{A} 2780^{\mathrm{ADR}}$ & $>10 \mu \mathrm{M}$ & $9.6 \mu \mathrm{M}$ & $3.4 \mu \mathrm{M}$ & $3.1 \mu \mathrm{M}$ & $735 \mathrm{nM}$ & $1.4 \mu \mathrm{M}$ & $1.3 \mu \mathrm{M}$ \\
\hline A $2780^{\text {CIS }}$ & $5.3 \mu \mathrm{M}$ & $3.7 \mu \mathrm{M}$ & $4.8 \mu \mathrm{M}$ & $2.4 \mu \mathrm{M}$ & $1.4 \mu \mathrm{M}$ & $176 \mathrm{nM}$ & $340 \mathrm{nM}$ \\
\hline
\end{tabular}

$\mathrm{B}, \mathrm{IC}_{50}$ values for other TKIs and cytotoxic agents

\begin{tabular}{|c|c|c|c|c|c|c|c|}
\hline Cell lines & NVP-AEW541 & Crizotinib & Imatinib & Dasatinib & Doxorubicin & Paclitaxel & Cisplatin \\
\hline $\mathrm{ES} 2$ & $3.5 \mu \mathrm{M}$ & $2.3 \mu \mathrm{M}$ & $>10 \mu \mathrm{M}$ & $1.6 \mu \mathrm{M}$ & $554 \mathrm{nM}$ & $13.9 \mathrm{nM}$ & $>20 \mu \mathrm{M}$ \\
\hline PA1 & $79.3 \mathrm{nM}$ & $162 \mathrm{nM}$ & $>10 \mu \mathrm{M}$ & $3.3 \mathrm{nM}$ & $169 \mathrm{nM}$ & $164 \mathrm{pM}$ & $1.5 \mu \mathrm{M}$ \\
\hline SKOV3 & $2.5 \mu \mathrm{M}$ & $2.3 \mu \mathrm{M}$ & $>10 \mu \mathrm{M}$ & $145 \mathrm{pM}$ & $207 \mathrm{nM}$ & $38.7 \mathrm{nM}$ & $>20 \mu \mathrm{M}$ \\
\hline CAOV3 & $2.1 \mu \mathrm{M}$ & $340 \mathrm{nM}$ & $>10 \mu \mathrm{M}$ & $4.7 \mathrm{nM}$ & $1.6 \mu \mathrm{M}$ & $102 \mathrm{pM}$ & $16.4 \mu \mathrm{M}$ \\
\hline COV318 & $1.6 \mu \mathrm{M}$ & $1.4 \mu \mathrm{M}$ & $>10 \mu \mathrm{M}$ & $2.7 \mathrm{nM}$ & $255 \mathrm{nM}$ & $116 \mathrm{nM}$ & $>20 \mu \mathrm{M}$ \\
\hline SW626 & $4.1 \mu \mathrm{M}$ & $2.6 \mu \mathrm{M}$ & $>10 \mu \mathrm{M}$ & $471 \mathrm{pM}$ & $2.2 \mu \mathrm{M}$ & $28.9 \mathrm{nM}$ & $>20 \mu \mathrm{M}$ \\
\hline OVCAR3 & $2.5 \mu \mathrm{M}$ & $906 \mathrm{nM}$ & $>10 \mu \mathrm{M}$ & $26.7 \mathrm{nM}$ & $1.2 \mu \mathrm{M}$ & $278 \mathrm{nM}$ & $16.5 \mu \mathrm{M}$ \\
\hline A2780 & $4.9 \mu \mathrm{M}$ & $333 \mathrm{nM}$ & $>10 \mu \mathrm{M}$ & $3.3 \mu \mathrm{M}$ & $154 \mathrm{nM}$ & $440 \mathrm{nM}$ & $13.3 \mu \mathrm{M}$ \\
\hline $\mathrm{A} 2780^{\mathrm{ADR}}$ & $6.5 \mu \mathrm{M}$ & $2.7 \mu \mathrm{M}$ & $>10 \mu \mathrm{M}$ & $3.0 \mathrm{nM}$ & $2.4 \mu \mathrm{M}$ & $114 \mathrm{nM}$ & $>20 \mu \mathrm{M}$ \\
\hline A $2780^{\mathrm{CIS}}$ & $2.3 \mu \mathrm{M}$ & $808 \mathrm{nM}$ & $>10 \mu \mathrm{M}$ & $3.3 \mu \mathrm{M}$ & $43.3 \mathrm{nM}$ & $754 \mathrm{pM}$ & $>20 \mu \mathrm{M}$ \\
\hline
\end{tabular}

increased the proportion of apoptotic/dead cells in sub- $\mathrm{G}_{1}$ phase (i.e., from 2 to 31 and 16\%) and this was accompanied by a significant increase in the proportion of cells in $\mathrm{G}_{2}-\mathrm{M}$ phase (i.e., from 8 to 28 and 54\%) and a slight increase in S phase of the cell cycle (i.e., from 7 to 13 and 12\%) respectively (Table III). Treatment of SKOV3 cells with various TKIs (erlotinib, afatinib, crizotinib, NVP-AEW541) also increased the proportion of cells in sub- $\mathrm{G}_{1}$ phase, but this was accompanied by a reduction in the proportion of cells in $\mathrm{S}$ phase of the cell cycle (Table III).

Growth response of human ovarian tumour cells to treatment with NVP-AEW541 in combination with afatinib, erlotinib, crizotinib and paclitaxel. In some studies, IGF-IR cross-talk with HER family members was associated with resistance to treatment with the HER inhibitors (please see Discussion e.g., refs. 58-60). As a result, we next examined the effect of IGF-IR TKI in combination with other agents on the growth of three human ovarian cancer cell lines. When NVP-AEW541 was combined with the reversible EGFR TKI erlotinib, there was an antagonistic response in all three ovarian cancer cell lines (SKOV3, Caov3 and ES2). When combined with afatinib there was a synergistic effect only in the HER-2 over-
Table III. Effect of afatinib, erlotinib, crizotinib, NVP-AEW541 and cytotoxic agents on the cell cycle distribution of ovarian SKOV3 cancer cell line.

\begin{tabular}{lcccc}
\hline Treatment & Sub- $_{0}$ & $\mathrm{G}_{0}-\mathrm{G}_{1}$ & $\mathrm{~S}$ & $\mathrm{G}_{2}-\mathrm{M}$ \\
\hline Medium & 2 & 82 & 7 & 8 \\
Erlotinib & 15 & 64 & 5 & 12 \\
Afatinib & 20 & 60 & 5 & 11 \\
Crizotinib & 34 & 8 & 3 & 18 \\
NVP-AEW541 & 9 & 58 & 7 & 22 \\
Paclitaxel & 32 & 12 & 13 & 28 \\
Doxorubicin & 16 & 14 & 12 & 54 \\
\hline
\end{tabular}

Each population is expressed as a percentage of gated cells.

expressing SKOV3 cells (Table IV). Next, we examined the effect of NVP-AEW541 in combination with crizotinib and this combination resulted in the synergistic growth inhibition of both SKOV3 and Caov3 cells, but it was antagonistic in ES2 cells. Finally, when NVP-AEW541 was used in combination 
Table IV. Mean combination index values of NVP-AEW541 when combined with afatinib, erlotinib, crizotinib and paclitaxel in human ovarian cancer cell lines.

Mean combination index (effect)

Cell line NVP-AEW541 + afatinib NVP-AEW541 + erlotinib NVP-AEW541 + crizotinib NVP-AEW541 + paclitaxel

\begin{tabular}{lllll}
\hline SKOV3 & 0.88 (slight synergism) & 1.64 (antagonism) & 0.10 (strong synergism) & 0.96 (nearly additive) \\
CAOV3 & 1.3 (moderate antagonism) & 1.83 (antagonism) & 0.20 (strong synergism) & 0.30 (strong synergism) \\
ES2 & 1.87 (moderate antagonism) & 5.54 (strong antagonism) & 2.5 (strong antagonism) & 0.89 (slight synergism)
\end{tabular}

${ }^{a}$ The degree of antagonism or synergism was calculated by Calcusyn software. Each value is the mean of three independent experiments.

A

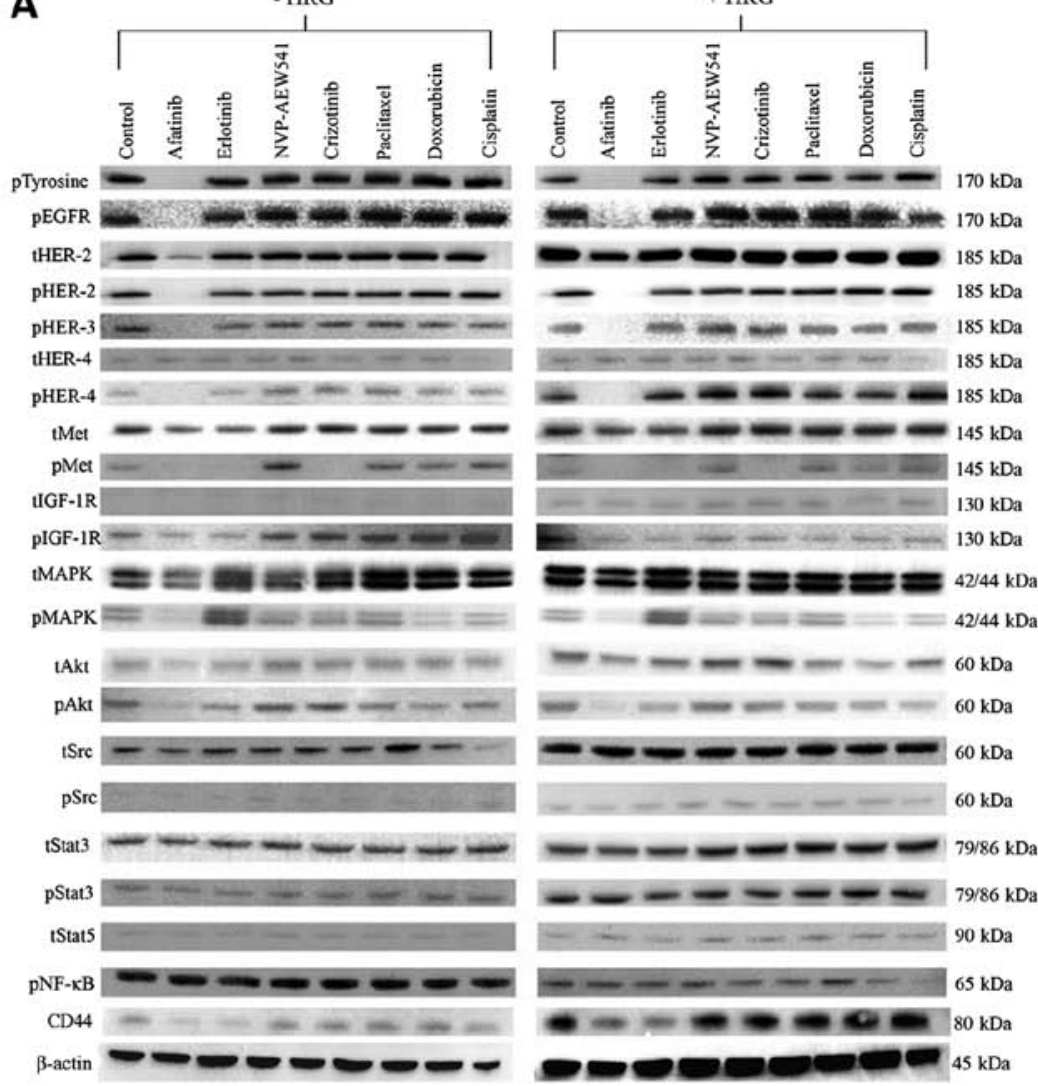

B

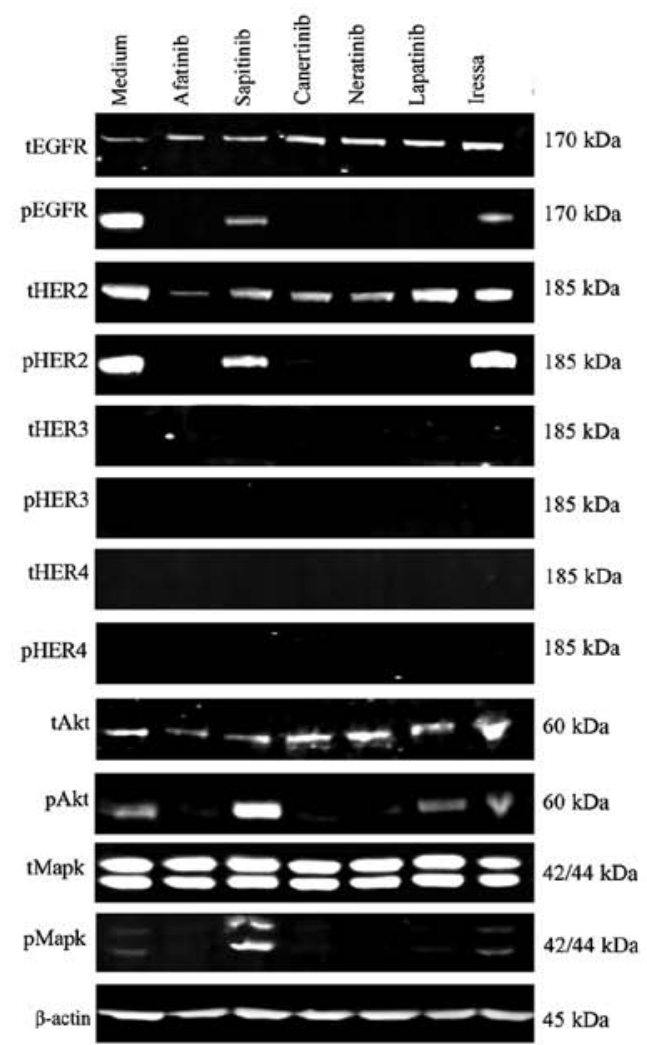

Figure 2. (A) Effect of various forms of HER TKIs on the basal level of phosphorylated HER family members and downstream cell signaling molecules in SKOV3 cells analysed on LI-COR Odyssey Scanner as described in Materials and methods. (B) Effect of afatinib, erlotinib, NVP-AEW541 crizotinib, paclitaxel, doxorubicin and cisplatin on the basal level and HRG-induced phosphorylation of HER family, IGF-1R, Met, and downstream cell signaling molecules, and on the expression level of CD44, in SKOV3 cells.

paclitaxel, this resulted in the synergistic or additive growth inhibition of all three ovarian cancer cells (Table IV).

Correlation analysis of the HER family members, IGF-1R, $A L K$ and c-Met and sensitivity to tyrosine kinase inhibitors and cytotoxic drugs. Linear regression analysis was carried out for determining the association between expression of growth factor receptors and sensitivity to the tyrosine kinase inhibitors as well as the cytotoxic drugs. There was no significant association between the expression of EGFR, HER-2, IGF-IR, c-MET, ALK and putative CSC markers and the response to treatment with the irreversible HER TKIs, dasatinib,
NVP-AEW541, and crizotinib. However, a significant association was found between the co-expression of CD24/HER-2, HER2/CD24/CD44, and EGFR/HER2/CD24 and response to treatment with gefitinib and lapatinib, and the co-expression of EGFR/HER2/CD24 and response to sapitinib (Table V). In addition, the co-expression of CD44 with EGFR, HER2, CD24, EGFR/CD24, HER2/CD24, EGFR/HER2, or EGFR/ HER2/CD24 was associated with better response to treatment with paclitaxel.

Treatment with the irreversible HER TKI afatinib is highly effective in reducing the phosphorylation of HER1-4, AKT, 


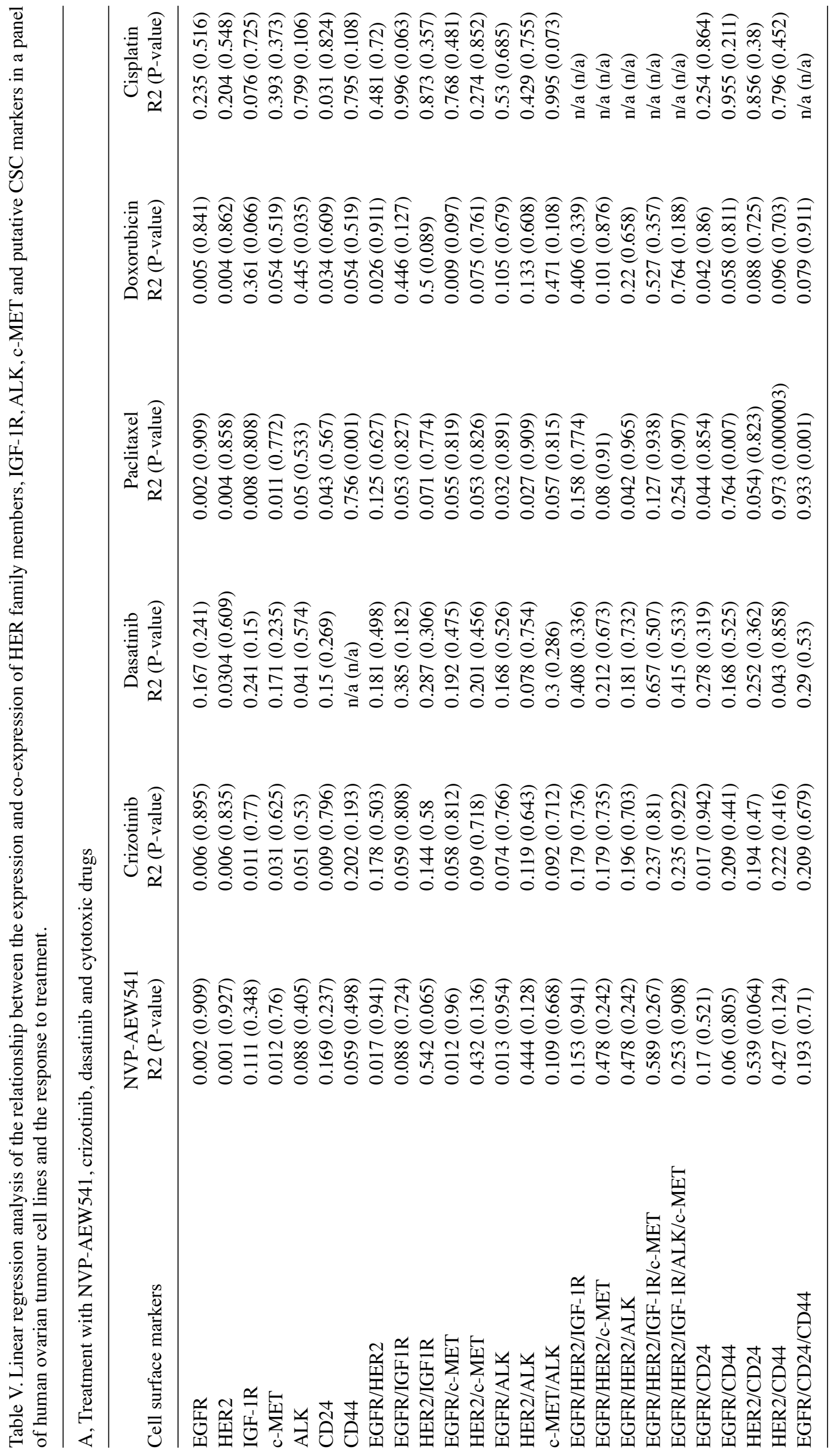

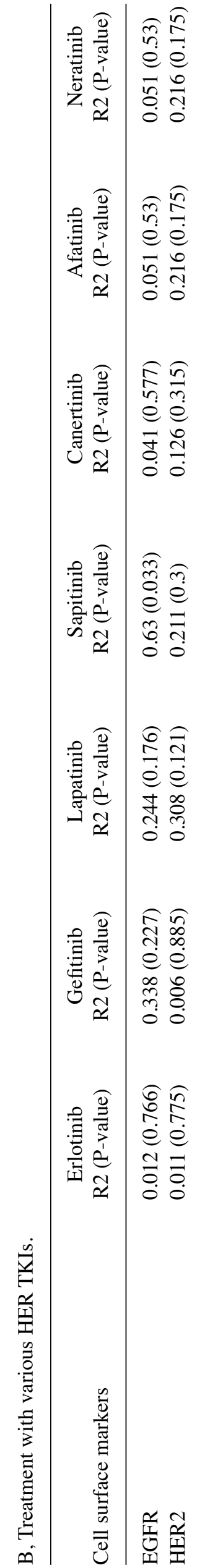




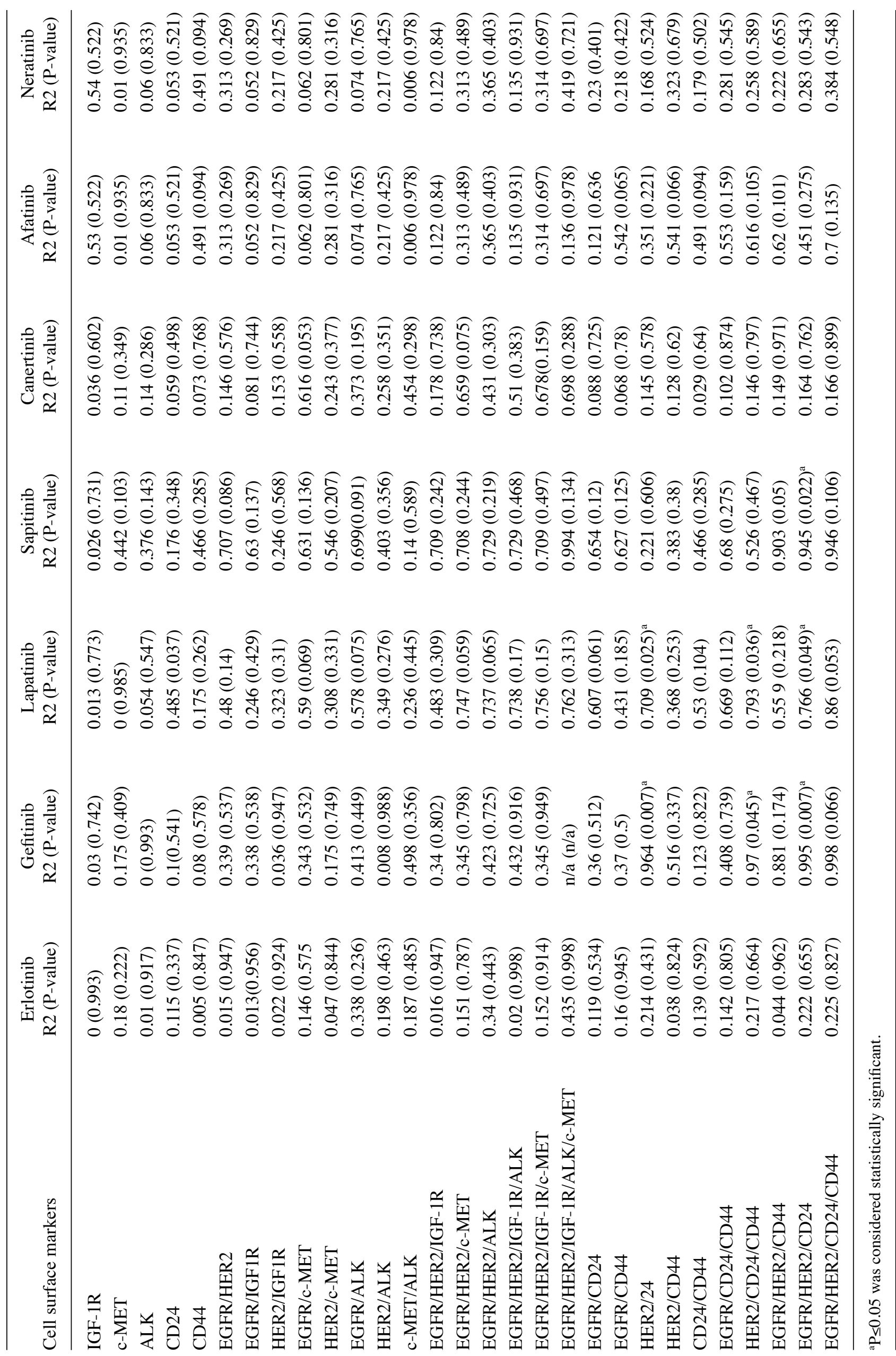




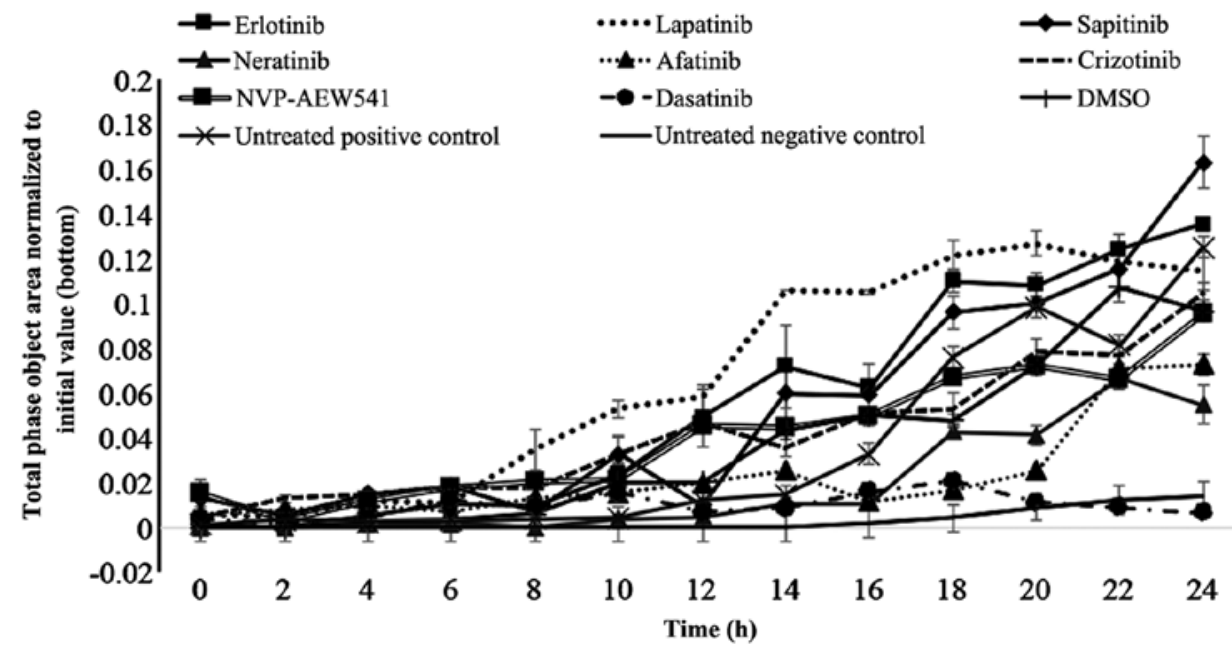

Figure 3. The effect of erlotinib, lapatinib, sapitinib, afatinib, neratinib, crizotinib, NVP-AEW541 and dasatinib on SKOV3 cell migration determined using the IncuCyte Clear View 96-well IncuCyte Chemotaxis system. Chamber wells were analysed every 3 hours using the IncuCyte chemotaxis software.

MAPK and CD44 expression in ovarian cancer cells. Next, we investigated the effect of various forms of the HER inhibitors on the basal phosphorylation of the HER family members and the downstream cell signaling molecules in SKOV3 cells. With the exceptions of treatment with gefitinib and sapitinib, all other HER TKIs induced complete inhibition of phosphorylated EGFR, HER-2 and AKT and MAPK (Fig. 2A). We also compared the effect of afatinib, erlotinib with those of NVP-AEW541, crizotinib and three cytotoxic drugs on heregulin-induced cell signaling. Of these, only afatinib was an effective agent in inhibiting both the constitutive phosphorylation and heregulin-induced phosphorylation of HER family members, c-MET, IGF-IR as well as MAPK and AKT (Fig. 2B). Moreover, treatment with both afatinib and erlotinib were accompanied by a reduction in the expression of CD44 in such cells (Fig. 2B).

Treatment with afatinib, neratinib and dasatinib inhibited the migration of SKOV3 cells. Finally, we investigated the migration of SKOV3 cells and whether treatment with various TKIs had any effect on the migration ability of these cells. Of these, only treatment with afatinib $(\mathrm{p}=0.027)$, neratinib $(\mathrm{p}=0.011)$ and dasatinib $(\mathrm{p}=0.004)$ produced a significant reduction in migration of SKOV3 cells (Fig. 3). Interestingly, treatment with sapitinib was accompanied by an increase in the migration of SKOV3 cells (Fig. 3).

\section{Discussion}

Ovarian cancer is one of the most lethal types of gynecological cancer. A significant proportion of ovarian cancer patients are diagnosed at the advanced stage of the disease and have a poor response to current chemotherapeutic interventions $(2,33,34)$. It is therefore considered essential to not only to develop more effective and less toxic therapeutic agents for the management of such patients, but also to identify more reliable biomarkers for earlier diagnosis, predicting the response, and guiding the treatment $(2,3,6,8,16,35,36)$. As noted earlier, the aberrant activation of the cell signaling pathways by the epidermal growth factor receptor members have been reported in a wide range of human cancers including ovarian cancer, and this has been associated with a poorer prognosis in many such patients $(37,38)$. To date, several anti-EGFR and anti-HER-2 monoclonal antibodies and various forms of small molecule TKIs, with specificity for one more member of the HER family, have been approved for the treatment of patients with a wide range of epithelial cancers $(11,17,18,39)$. However, none has yet been approved for the treatment of patients with ovarian cancer (7,22-24,40-47). Some of the contributing factors may include the heterogeneous nature of ovarian cancer, the presence of alternative pathways for tumour cell proliferation, the absence of reliable predictive biomarkers for the selection of a more specific population of ovarian cancer patients who may benefit from such therapeutic interventions, and the presence of chemoresistant cancer stem cells (48-51).

In this study, for the first time to our knowledge, we examined the growth response of 10 human ovarian cancer cell lines to treatment with various forms of the EGFR TKIs including reversible EGFR specific, reversible dual EGFR/HER-2 TKI and reversible and irreversible pan-HER family inhibitors, as wells as other TKIs and cytotoxic drugs. We also examined whether there was any association between the expression of HER family members, putative ovarian cancer stem cell markers or P-glycoprotein and response to these agents. Of the HER inhibitors tested, we found that treatment with the 3 irreversible pan-HER family TKIs (i.e., canertinib, neratinib and afatinib) were more effective than treatment with the EGFR specific TKIs gefitinib and erlotinib, the dual EGFR/HER-2 TKI lapatinib or the reversible pan EGFR/HER-2/HER-3 TKI sapitinib, by inhibiting the growth of all ovarian cancer cell lines at concentrations $<3.5 \mu \mathrm{M}$ (Table II and Fig. 1A). Unlike small molecule EGFR TKIs, anti-EGFR antibody cetuximab, which has been approved for the treatment of patients with colorectal and head and neck cancers, blocks EGFR signaling by inhibiting the binding of ligands to the external domain of the EGFR (20). In another study, Bull Phelps and colleagues examined the effect of gefitinib and cetuximab on the growth in vitro of 9 ovarian cancer cell lines. They found gefitinib 
to inhibit the growth of these nine ovarian cancer cell lines with $\mathrm{IC}_{50}$ values ranging from 6.72 to $32.27 \mu \mathrm{M}$. In contrast, they could not calculate the $\mathrm{IC}_{50}$ value for cetuximab as it was greater than the highest dose tested $(1,700 \mu \mathrm{M})(52)$. In another study, Glaysher and colleagues examined the growth response of primary ovarian cell cultures to treatment with gefitinib and erlotinib and found only 2 out of 9 and 1 out of 9 had strong single agent activity respectively (53). In this study, while the irreversible pan-HER-family inhibitors had more anti-proliferative effect than the other forms of the EGFR TKIs, the pattern of growth inhibition of the ovarian cancer cell lines by the three irreversible pan-HER TKI were not identical (Table II and Fig. 1A). We also examined the effect of the HER inhibitors on the constitutive phosphorylation of the HER family members and downstream cell signaling molecules in SKOV3 cells and found that only treatment with the three irreversible pan-HER TKIs resulted in complete inhibition of autophosphorylated EGFR, HER-2, AKT and MAPK (Fig. 2A). In addition, of the HER-inhibitors studied, only treatment with neratinib and afatinib resulted in a significant reduction in the migration of the HER-2 overexpressing SKOV3 cells (Fig. 3). Interestingly, we did not find any significant association between the expression level of one or more members of the HER family and growth response to these inhibitors (Table V).

In some studies, the co-expression of other growth factor receptors and over-activation of downstream cell signaling molecules have been associated with resistance of tumour cells to treatment with the HER inhibitors and cytotoxic drugs $(30,33,54-59)$. As a result, we next examined the expression level of IGF-IR, c-MET, ALK in these cancer cell lines and their predictive value for response to treatment with the corresponding TKIs, the HER-inhibitors, dasatinib and cytotoxic drugs. While some of the cell lines expressed low level of IGF-IR, ALK and c-MET, we did not find any significant association between the expression level of these biomarkers and response to treatment with the TKIs and cytotoxic drugs (Tables I and V). Next, we investigated the effect of the IGF-IR TKI in combination with the irreversible pan-HER family blocker afatinib, the irreversible EGFR TKI erlotinib, crizotinib or paclitaxel on the growth of three ovarian cancer cells. We found that the combination of NVP-AEW541 with erlotinib was antagonistic in all three ovarian cancer cells. In contrast, treatment with a combination of NVP-AEW541 with afatinib or crizotinib resulted in synergistic growth inhibition of the HER-2 overexpressing and EGFR/IGF-IR/C-Met positive SKOV3 but the same combinations were antagonistic in

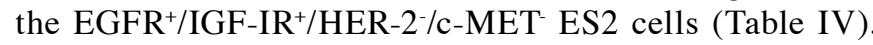
In other studies while treatment with a combination of the IGF-IR TKI with the HER inhibitors resulted in synergistic or additive cytotoxic effects in a panel of colorectal and pancreatic cancer cells, the same combination was found to be antagonistic in a sub-set of such tumour cell lines $(31,60)$ This highlights the complexity and heterogeneous nature of cross-talk between the IGF-IR and the HER family members and c-MET by different ovarian cancer cells. Interestingly, only treatment with a combination of NVP-AEW541 and paclitaxel resulted in the synergistic growth inhibition of all three ovarian cancer cells (Table III). In another study, Beltran and colleagues investigated the antitumour activity of the fully human anti-IGF-IR antibody ganitumab with pacli- taxel or carboplatin in a panel of ovarian cancer cell lines and found that treatment with a combination of ganitumab with paclitaxel or carboplatin resulted in synergistic and additive growth inhibition of these cancer cell lines (61). Therefore, further investigations are warranted on the therapeutic potential of the IGF-IR inhibitor in combination paclitaxel in ovarian cancer.

In several malignancies including ovarian cancer, the presence of a rare population of cancer stem cells have been suggested as the cause of tumour progression, metastasis and resistance to chemotherapy $(50,62-66)$. As there is currently no specific ovarian cancer stem cell marker, we next investigated the expression level and predictive value of three putative cancer stem cell markers (CD24, CD44, CD117/c-Kit) for the response to treatment with various TKIs and cytotoxic agents in our panel of ovarian cancer cells. We found five and seven ovarian cancer cell lines to be CD24- and CD44-positive, respectively (Table I). In some studies, CD44 expression has been associated with epithelial to mesenchymal transition and shorter disease-free and overall survival in patients with ovarian cancer $(67,68)$. In this study, we found that treatment of SKOV3 cells with both afatinib and erlotinib was accompanied by the downregulation of CD44 (Fig. 2B). In another study, Su and colleagues found that downregulation of CD24 in SKOV3 cells was accompanied by a significant reduction in cell viability and induction of apoptosis in SKOV3 cells (69). More recently, Burgos-Ojeda and colleagues showed that CD24 ${ }^{+}$ovarian cancer cells are enriched with cancer initiating cells and play an important role in tumour initiation and metastasis (70). However, while there was overexpression of CD44 and CD24 in several of the ovarian cancer cell lines used in this study, none of them were CD117/c-Kit-positive or had overexpression of P-glycoprotein (Table I). Moreover, while there was not a significant association between the expression of CD44 or CD24 and the response to treatment with TKIs and cytotoxic drugs, a significant association was found between the co-expression of HER-2/CD24, HER2/CD24/CD44 and EGFR/CD24/CD44 the response to treatment with gefitinib and lapatinib, and the co-expression of EGFR/HER2/CD24 and EGFR/HER2/CD44 and the response to treatment with sapitinib. Of the three cytotoxic drugs, we found that paclitaxel was the most effective drug for inhibiting the growth of ovarian tumour cell lines with concentrations ranging from pico molar concentrations and none $>440 \mathrm{nM}$. Interestingly, the co-expression of CD44/CD24 with EGFR, HER-2 or EGFR/ HER-2 were all associated with response to paclitaxel but not doxorubicin or cisplatin (Table V). These results support the need for further investigation on the predictive value of these biomarkers for response to treatment with paclitaxel in ovarian cancer patients.

Finally, the downstream signaling protein Src is a known key signaling pathway inducer of several membrane bound activated receptors, including EGFR. The result of a clinical trial with the SRC-family kinase inhibitor dasatinib suggested that it has minimal activity as a single agent in the treatment of patients with recurrent or persistent epithelial ovarian carcinoma (71). However, in several preclinical studies treatment with dasatinib in combination with a chemotherapeutic resulted in synergistic growth inhibition of some of the ovarian cancer cell lines (72-75). We found that dasatinib was the most 
potent TKI in this study. While dasatinib inhibited the growth of all ovarian cancer cell lines in our study and it was the most effective TKI for inhibiting SKOV3 cell migration, there was a 4-log-fold difference in its $\mathrm{IC}_{50}$ value ranging from $145 \mathrm{pM}$ in SKOV 3 cells to $3.3 \mu \mathrm{M}$ in A2780 ${ }^{\mathrm{CIS}}$ cells (Table II and Figs. $1 \mathrm{~B}$ and 3). This highlights the importance of the identification of reliable predictive biomarkers for directing dasatinib therapy, in particular further studies on its therapeutic potential when used in combination with the irreversible HER inhibitors or other chemotherapeutic agents, in ovarian cancer.

In conclusion, our results show that of the HER TKIs, the irreversible pan-HER TKIs were more effective at inhibiting the growth of ovarian cancer cells, blocking cell signalling through HER family members and reducing the migration of ovarian cancer cells. Moreover, of all the TKIs and the three cytotoxic drugs used in our study, we found that the great majority of ovarian cancer cells were most sensitive to treatment with the $\mathrm{Src} / \mathrm{V}$-abl/C-kit inhibitor dasatinib and paclitaxel respectively. The variation in growth suppression of various EGFR TKIs across the panel of human ovarian tumour cell lines also highlights the important role of tumour heterogeneity. Our results support the need for further investigations of the therapeutic potential of irreversible HER family blockers in ovarian cancer, and the therapeutic potential of dasatinib when used in combination with the inhibitors of the HER family members.

\section{Acknowledgements}

This study was supported by Kingston University London and in part by GRACE cancer charity (UK). We are grateful to OSI Pharmaceuticals, Boehringer Ingelheim and Novartis for providing OSI-774 and BIBW2992 and NVP-AEW541, respectively, for the use in this study.

\section{References}

1. Ferlay J, Soerjomataram I, Dikshit R, Eser S, Mathers C, Rebelo M, Parkin DM, Forman D and Bray F: Cancer incidence and mortality worldwide: Sources, methods and major patterns in GLOBOCAN 2012. Int J Cancer 136: E359-E386, 2015.

2. Hennessy BT, Coleman RL and Markman M: Ovarian cancer. Lancet 374: 1371-1382, 2009.

3. Aleksandra Kujawa K and Lisowska KM: Ovarian cancer - from biology to clinic. Postepy Hig Med Dosw Online 69: 1275-1290, 2015 (In Polish).

4. Petrillo M, De Iaco P, Cianci S, Perrone M, Costantini B, Ronsini C, Scambia G and Fagotti A: Long-term survival for platinum-sensitive recurrent ovarian cancer patients treated with secondary cytoreductive surgery plus hyperthermic intraperitoneal chemotherapy (HIPEC). Ann Surg Oncol 23: 1660-1665, 2016.

5. Dinkelspiel HE, Tergas AI, Zimmerman LA, Burke WM, Hou JY, Chen L, Hillyer G, Neugut AI, Hershman DL and Wright JD: Use and duration of chemotherapy and its impact on survival in early-stage ovarian cancer. Gynecol Oncol 137: 203-209, 2015.

6. Husseinzadeh N: Status of tumor markers in epithelial ovarian cancer has there been any progress? A review. Gynecol Oncol 120: 152-157, 2011.

7. Banerjee $S$ and Kaye $S$ : The role of targeted therapy in ovarian cancer. Eur J Cancer 47 (Suppl 3): S116-S130, 2011.

8. Gibson AJ , Krishnansu S Tewari KS, Monk BJ and Chase DM: updates on drug discovery in ovarian cancer. Gynecol Oncol Res Pract 1: 3, 2014.

9. Modjtahedi $\mathrm{H}$ and Dean C: The receptor for EGF and its ligands - expression, prognostic value and target for therapy in cancer (Review). Int J Oncol 4: 277-296, 1994.
10. Mendelsohn $\mathrm{J}$ and Baselga J: Epidermal growth factor receptor targeting in cancer. Semin Oncol 33: 369-385, 2006.

11. Arteaga CL and Engelman JA: ERBB receptors: From oncogene discovery to basic science to mechanism-based cancer therapeutics. Cancer Cell 25: 282-303, 2014.

12. Mass RD: The HER receptor family: A rich target for therapeutic development. Int J Radiat Oncol Biol Phys 58: 932-940, 2004.

13. Hanahan D and Weinberg RA: Hallmarks of cancer: The next generation. Cell 144: 646-674, 2011.

14. Roskoski R Jr: ErbB/HER protein-tyrosine kinases: Structures and small molecule inhibitors. Pharmacol Res 87: 42-59, 2014.

15. Appert-Collin A, Hubert P, Crémel G and Bennasroune A: Role of ErbB Receptors in Cancer Cell Migration and Invasion. Front Pharmacol 6: 283, 2015.

16. Lafky JM, Wilken JA, Baron AT and Maihle NJ: Clinical implications of the ErbB/epidermal growth factor (EGF) receptor family and its ligands in ovarian cancer. Biochim Biophys Acta 1785: 232-265, 2008.

17. Ioannou N, Seddon AM, Dalgleish A, Mackintosh D and Modjtahedi H: Expression pattern and targeting of HER family members and IGF-IR in pancreatic cancer. Front Biosci (Landmark Ed) 17: 2698-2724, 2012.

18. Khelwatty SA, Essapen S, Seddon AM and Modjtahedi H: Prognostic significance and targeting of HER family in colorectal cancer. Front Biosci (Landmark Ed) 18: 394-421, 2013.

19. Davies S, Holmes A, Lomo L, Steinkamp MP, Kang H, Muller CY and Wilson BS: High incidence of ErbB3, ErbB4, and MET expression in ovarian cancer. Int J Gynecol Pathol 33: 402-410, 2014.

20. Modjtahedi H, Ali S and Essapen S: Therapeutic application of monoclonal antibodies in cancer: Advances and challenges. $\mathrm{Br}$ Med Bull 104: 41-59, 2012.

21. Serrano-Olvera A, Dueñas-González A, Gallardo-Rincón D, Candelaria M and De la Garza-Salazar J: Prognostic, predictive and therapeutic implications of HER2 in invasive epithelial ovarian cancer. Cancer Treat Rev 32: 180-190, 2006.

22. Langdon SP, Faratian D, Nagumo Y, Mullen P and Harrison DJ: Pertuzumab for the treatment of ovarian cancer. Expert Opin Biol Ther 10: 1113-1120, 2010.

23. Sheng Q and Liu J: The therapeutic potential of targeting the EGFR family in epithelial ovarian cancer. Br J Cancer 104: 1241-1245, 2011.

24. Kaye SB, Poole CJ, Dańska-Bidzińska A, Gianni L, Del Conte G, Gorbunova V, Novikova E, Strauss A, Moczko M, McNally VA, et al: A randomized phase II study evaluating the combination of carboplatin-based chemotherapy with pertuzumab versus carboplatin-based therapy alone in patients with relapsed, platinum-sensitive ovarian cancer. Ann Oncol 24: 145-152, 2013.

25. Dutta DK and Dutta I: Origin of ovarian cancer: Molecular profiling. J Obstet Gynaecol India 63: 152-157, 2013.

26. Reyes HD, Thiel KW, Carlson MJ, Meng X, Yang S, Stephan JM and Leslie KK: Comprehensive profiling of EGFR/HER receptors for personalized treatment of gynecologic cancers. Mol Diagn Ther 18: 137-151, 2014.

27. Bapat SA: Human ovarian cancer stem cells. Reproduction 140: 33-41, 2010.

28. Walters Haygood CL, Arend RC, Straughn JM and Buchsbaum DJ: Ovarian cancer stem cells: Can targeted therapy lead to improved progression-free survival? World J Stem Cells 6: 441-447, 2014.

29. Zhao J, Klausen C, Qiu X, Cheng JC, Chang HM and Leung PC: Betacellulin induces Slug-mediated down-regulation of E-cadherin and cell migration in ovarian cancer cells. Oncotarget: Feb 22, 2016 (Epub ahead of print). doi: 10.18632/oncotarget.7591.

30. Cunningham MP, Thomas H, Fan Z and Modjtahedi $\mathrm{H}$ : Responses of human colorectal tumor cells to treatment with the anti-epidermal growth factor receptor monoclonal antibody ICR62 used alone and in combination with the EGFR tyrosine kinase inhibitor gefitinib. Cancer Res 66: 7708-7715, 2006.

31. Khelwatty SA,Essapen S, Seddon AM and Modjtahedi H: Growth response of human colorectal tumour cell lines to treatment with afatinib (BIBW2992), an irreversible erbB family blocker, and its association with expression of HER family members. Int J Oncol 39: 483-491, 2011.

32. Ioannou N, Dalgleish AG, Seddon AM, Mackintosh D, Guertler U, Solca F and Modjtahedi H: Anti-tumour activity of afatinib, an irreversible ErbB family blocker, in human pancreatic tumour cells. Br J Cancer 105: 1554-1562, 2011. 
33. Davis A, Tinker AV and Friedlander M: 'Platinum resistant' ovarian cancer: What is it, who to treat and how to measure benefit? Gynecol Oncol 133: 624-631, 2014.

34. Dinkelspiel HE, Champer M, Hou J, Tergas A, Burke WM, Huang Y, Neugut AI, Ananth CV, Hershman DL and Wright JD: Long-term mortality among women with epithelial ovarian cancer. Gynecol Oncol 138: 421-428, 2015.

35. Chase DM, Mathur N and Tewari KS: Drug discovery in ovarian cancer. Recent Patents Anticancer Drug Discov 5: 251-260, 2010.

36. Bonneau C, Rouzier R, Geyl C, Cortez A, Castela M, Lis R, Daraï $\mathrm{E}$ and Touboul C: Predictive markers of chemoresistance in advanced stages epithelial ovarian carcinoma. Gynecol Oncol 136: 112-120, 2015.

37. Wilken JA, Badri T, Cross S, Raji R, Santin AD, Schwartz P, Branscum AJ, Baron AT, Sakhitab AI and Maihle NJ: EGFR/ HER-targeted therapeutics in ovarian cancer. Future Med Chem 4: 447-469, 2012.

38. Roskoski R Jr: The ErbB/HER family of protein-tyrosine kinases and cancer. Pharmacol Res 79: 34-74, 2014.

39. Modjtahedi H, Khelwatty SA, Kirk RS, Seddon AM, Essapen S, Del Vecchio CA, Wong AJ and Eccles S: Immunohistochemical discrimination of wild-type EGFR from EGFRvIII in fixed tumour specimens using anti-EGFR mAbs ICR9 and ICR10. Br J Cancer 106: 883-888, 2012.

40. Weroha SJ, Oberg AL, Ziegler KL, Dakhilm SR, Rowland KM, Hartmann LC, Moore DF Jr, Keeney GL, Peethambaram PP and Haluska P: Phase II trial of lapatinib and topotecan (LapTop) in patients with platinum-refractory/resistant ovarian and primary peritoneal carcinoma. Gynecol Oncol 122: 116-120, 2011

41. Lheureux S, Krieger S, Weber B, Pautier P, Fabbro M, Selle F, Bourgeois H, Petit T, Lortholary A, Plantade A, et al: Expected benefits of topotecan combined with lapatinib in recurrent ovarian cancer according to biological profile: A phase 2 trial. Int J Gynecol Cancer 22: 1483-1488, 2012.

42. Teplinsky E and Muggia F: Targeting HER 2 in ovarian and uterine cancers: Challenges and future directions. Gynecol Oncol 135: 364-370, 2014.

43. Nimeiri HS, Oza AM, Morgan RJ, Friberg G, Kasza K, Faoro L, Salgia R, Stadler WM, Vokes EE and Fleming GF; Chicago Phase II Consortium; PMH Phase II Consortium; California Phase II Consortium: Efficacy and safety of bevacizumab plus erlotinib for patients with recurrent ovarian, primary peritoneal, and fallopian tube cancer: A trial of the Chicago, $\mathrm{PMH}$ and California Phase II Consortia. Gynecol Oncol 110: 49-55, 2008.

44. Pautier P, Joly F, Kerbrat P, Bougnoux P, Fumoleau P, Petit T, Rixe O, Ringeisen F, Carrasco AT and Lhommé C: Phase II study of gefitinib in combination with paclitaxel $(\mathrm{P})$ and carboplatin $(\mathrm{C})$ as second-line therapy for ovarian, tubal or peritoneal adenocarcinoma (1839IL/0074). Gynecol Oncol 116: 157-162, 2010.

45. Garcia AA, Sill MW, Lankes HA, Godwin AK, Mannel RS, Armstrong DK, Carolla RL, Liepman MK, Spirtos NM, Fischer EG, et al: A phase II evaluation of lapatinib in the treatment of persistent or recurrent epithelial ovarian or primary peritoneal carcinoma: A gynecologic oncology group study. Gynecol Oncol 124: 569-574, 2012.

46. Vergote IB, Jimeno A, Joly F, Katsaros D, Coens C, Despierre E, Marth C, Hall M, Steer CB, Colombo N, et al: Randomized phase III study of erlotinib versus observation in patients with no evidence of disease progression after first-line platin-based chemotherapy for ovarian carcinoma: A European Organisation for Research and Treatment of Cancer-Gynaecological Cancer Group, and Gynecologic Cancer Intergroup study. J Clin Oncol 32: 320-326, 2014.

47. Campos SM, Berlin ST, Parker LM, Chen WY, Bunnell CA, Atkinson T, Lee J, Matulonis U, Hirsch MS, Harris L, et al: Phase I trial of liposomal doxorubicin and ZD1839 in patients with refractory gynecological malignancies or metastatic breast cancer. Int J Clin Oncol 15: 390-398, 2010.

48. Davidson B and Tropé CG: Ovarian cancer: Diagnostic, biological and prognostic aspects. Wom Health Lond 10: 519-533, 2014

49. Au KK, Josahkian JA, Francis JA, Squire JA and Koti M: Current state of biomarkers in ovarian cancer prognosis. Future Oncol 11: 3187-3195, 2015.

50. Albini A, Bruno A, Gallo C, Pajardi G, Noonan DM and Dallaglio K: Cancer stem cells and the tumor microenvironment: Interplay in tumor heterogeneity. Connect Tissue Res 56: $414-425,2015$
51. Davidson B: Recently identified drug resistance biomarkers in ovarian cancer. Expert Rev Mol Diagn 16: 569-578, 2016.

52. Bull Phelps SL, Schorge JO, Peyton MJ, Shigematsu H, Xiang LL, Miller DS and Lea JS: Implications of EGFR inhibition in ovarian cancer cell proliferation. Gynecol Oncol 109: 411-417, 2008.

53. Glaysher S, Bolton LM, Johnson P, Atkey N, Dyson M, Torrance $\mathrm{C}$ and Cree IA: Targeting EGFR and PI3K pathways in ovarian cancer. Br J Cancer 109: 1786-1794, 2013.

54. Viloria-Petit AM and Kerbel RS: Acquired resistance to EGFR inhibitors: Mechanisms and prevention strategies. Int J Radiat Oncol Biol Phys 58: 914-926, 2004.

55. Jones HE, Gee JM, Barrow D, Tonge D, Holloway B and Nicholson RI: Inhibition of insulin receptor isoform-A signalling restores sensitivity to gefitinib in previously de novo resistant colon cancer cells. Br J Cancer 95: 172-180, 2006.

56. Engelman JA, Zejnullahu K, Mitsudomi T, Song Y, Hyland C, Park JO, Lindeman N, Gale CM, Zhao X, Christensen J, et al: MET amplification leads to gefitinib resistance in lung cancer by activating ERBB3 signaling. Science 316: 1039-1043, 2007.

57. Mueller KL, Hunter LA, Ethier SP and Boerner JL: Met and c-Src cooperate to compensate for loss of epidermal growth factor receptor kinase activity in breast cancer cells. Cancer Res 68: 3314-3322, 2008

58. van der Veeken J, Oliveira S, Schiffelers RM, Storm G, van Bergen En Henegouwen PM and Roovers RC: Crosstalk between epidermal growth factor receptor- and insulin-like growth factor-1 receptor signaling: Implications for cancer therapy. Curr Cancer Drug Targets 9: 748-760, 2009.

59. Tandon R, Kapoor S, Vali S, Senthil V, Nithya D, Venkataramanan R, Sharma A, Talwadkar A, Ray A, Bhatnagar PK, et al: Dual epidermal growth factor receptor (EGFR)/insulin-like grow th factor-1 receptor (IGF-1R) inhibitor: A novel approach for overcoming resistance in anticancer treatment. Eur J Pharmacol 667: 56-65, 2011.

60. Ioannou N, Seddon AM, Dalgleish A, Mackintosh D and Modjtahedi $\mathrm{H}$ : Treatment with a combination of the ErbB (HER) family blocker afatinib and the IGF-IR inhibitor, NVP-AEW541 induces synergistic growth inhibition of human pancreatic cancer cells. BMC Cancer 13: 41, 2013.

61. Beltran PJ, Calzone FJ, Mitchell P, Chung YA, Cajulis E, Moody G, Belmontes B, Li CM, Vonderfecht S, Velculescu VE, et al: Ganitumab (AMG 479) inhibits IGF-II-dependent ovarian cancer growth and potentiates platinum-based chemotherapy. Clin Cancer Res 20: 2947-2958, 2014.

62. Filip S, English D and Mokrý J: Issues in stem cell plasticity. J Cell Mol Med 8: 572-577, 2004.

63. Bellantuono I: Haemopoietic stem cells. Int J Biochem Cell Biol 36: 607-620, 2004

64. Trounson A: Stem cells, plasticity and cancer - uncomfortable bed fellows. Development 131: 2763-2768, 2004.

65. Zhou Q, Chen A, Song H, Tao J, Yang H and Zuo M: Prognostic value of cancer stem cell marker CD133 in ovarian cancer: A meta-analysis. Int J Clin Exp Med 8: 3080-3088, 2015.

66. Saito $\mathrm{T}$ and Mimori K: Cancer stemness and circulating tumor cells. Nihon Rinsho 73: 806-810, 2015 (In Japanese).

67. Sacks JD and Barbolina MV: Expression and function of CD44 in epithelial ovarian carcinoma. Biomolecules 5: 3051-3066, 2015.

68. Elzarkaa AA, Sabaa BE, Abdelkhalik D, Mansour H, Melis M, Shaalan W, Farouk M, Malik E and Soliman AA: Clinical relevance of CD44 surface expression in advanced stage serous epithelial ovarian cancer: A prospective study. J Cancer Res Clin Oncol 142: 949-958, 2016.

69. Su D, Deng H, Zhao X, Zhang X, Chen L, Chen X, Li Z, Bai Y, Wang Y, Zhong Q, et al: Targeting CD24 for treatment of ovarian cancer by short hairpin RNA. Cytotherapy 11: 642-652, 2009.

70. Burgos-Ojeda D, Wu R, McLean K, Chen YC, Talpaz M, Yoon E, Cho KR and Buckanovich RJ: CD24+ ovarian cancer cells are enriched for cancer-initiating cells and dependent on JAK2 signaling for growth and metastasis. Mol Cancer Ther 14: $1717-1727,2015$

71. Schilder RJ, Brady WE, Lankes HA, Fiorica JV, Shahin MS, Zhou XC, Mannel RS, Pathak HB, Hu W, Alpaugh RK, et al: Phase II evaluation of dasatinib in the treatment of recurrent or persistent epithelial ovarian or primary peritoneal carcinoma: A Gynecologic Oncology Group study. Gynecol Oncol 127: 70-74, 2012 . 
72. Konecny GE, Glas R, Dering J, Manivong K, Qi J, Finn RS, Yang GR, Hong KL, Ginther C, Winterhoff B, et al: Activity of the multikinase inhibitor dasatinib against ovarian cancer cells. Br J Cancer 101: 1699-1708, 2009.

73. Teoh D, Ayeni TA, Rubatt JM, Adams DJ, Grace L, Starr MD, Barry WT, Berchuck A, Murphy SK and Secord AA: Dasatinib (BMS-35482) has synergistic activity with paclitaxel and carboplatin in ovarian cancer cells. Gynecol Oncol 121: 187-192, 2011.
74. Xiao J, Xu M, Hou T, Huang Y, Yang C and Li J: Dasatinib enhances antitumor activity of paclitaxel in ovarian cancer through Src signaling. Mol Med Rep 12: 3249-3256, 2015.

75. Secord AA, Teoh D, Jia J, Nixon AB, Grace L, Adams DJ and Murphy SK: Dasatinib (BMS-35482) interacts synergistically with docetaxel, gemcitabine, topotecan, and doxorubicin in ovarian cancer cells with high SRC pathway activation and protein expression. Int J Gynecol Cancer 24: 218-225, 2014 